\title{
Intimate partner violence and its contribution to mental disorders in men and women in the post genocide Rwanda: findings from a population based study
}

Aline Umubyeyi ${ }^{1} 2^{*}$, Ingrid Mogren ${ }^{3}$, Joseph Ntaganira ${ }^{1}$ and Gunilla Krantz ${ }^{2}$

\begin{abstract}
Background: In low income countries, mental disorders are a neglected health problem. Mental disorders are influenced by a number of factors in people's everyday life of which intimate partner violence (IPV) commonly form an important part. The aim of this study was to investigate the prevalence of mental disorders in young men and women in Rwanda and their risk factors with main emphasis on IPV and its contribution to mental disorders, taking into account the genocide context.

Methods: This population-based study included a representative sample of 917 men and women aged 20-35 years. The prevalence of mental disorders was investigated using of a diagnostic tool, the "MINI: Mini International Neuropsychiatric Interview". Risk factor patterns were analysed with bi- and multivariate logistic regression. To find the proportion of mental disorders attributed to IPV, the population attributable fraction was computed.

Results: The prevalence rates of current depression, suicide risk and PTSD were more than two times higher in women than in men while for generalized anxiety disorder, the prevalence was about the same. Physical, sexual and psychological intimate partner violence exposure was highly associated with all forms of mental disorders for women. For physical violence, after adjusting for socio-demographic factors and exposure to traumatic episodes during the Rwandan genocide, the risk of current depression for women was elevated four times. Even though few men reported partner violence exposure, physical violence in the past year was found to be a statistically significant risk factor for current depression and for generalized anxiety disorder. However, having an experience of traumatic episodes during the genocide contributed to the risk of most of mental disorders investigated for men.
\end{abstract}

Conclusion: In Rwanda, IPV contributed considerably to mental disorders investigated. Thus, prevention of IPV should be considered as a public health priority, as its prevention would considerably reduce the prevalence of mental disorders.

Keywords: Intimate partner violence, Mental disorder, Men, Women, Genocide, Rwanda

\section{Background}

Mental disorders constitute a threat to individuals, families and countries well-being; about 450 million people worldwide suffer from a mental disorder [1]. These kinds of diseases contribute to about $14 \%$ of the global burden of disease [1] and $30 \%$ of the total non-communicable

\footnotetext{
* Correspondence: aumubyey@nursph.org

'Department of Epidemiology and Biostatistics, School of Public health, College of Medicine and Health Sciences, University of Rwanda, Kigali, Rwanda

${ }^{2}$ Department of Public Health and Community Medicine, Sahlgrenska

Academy at Gothenburg University, Gothenburg, Sweden

Full list of author information is available at the end of the article
}

disease burden all over the world [2]. Moreover, mental disorders are among the most neglected conditions worldwide [2], they strike young people in their productive and reproductive age, with devastating effects not only for the victim but for the entire family. However, it often goes unrecognized and untreated in most low and middle-income countries [3].

Studies are increasingly demonstrating that intimate partner violence (IPV) has a negative impact on women's health $[4,5]$. At a global level, it is acknowledged that IPV directed towards women is associated with a number of 
health effects such as injuries, mental health problems, HIV, pain and cardio-vascular problems [5]. The latest World Health Organization (WHO) report on IPV and its health effects indicates that women who are physically or sexually abused by their partners are almost twice as likely to experience depression compared to unexposed women [4]. A review of studies in high income countries has shown a variation in IPV prevalence across countries and, irrespective of the difference in magnitude, IPV is associated with a range of mental disorders including depression, PTSD, anxiety, self-harm and sleep-disorders [5]. A study from Australia has found that IPV among 18-44 year old women accounted for $7.9 \%$ of the overall burden of disease [6].

The situation in low and middle income countries is comparable $[7,8]$. A study conducted in Ethiopia highlighted that physical violence, high spousal control of women by the partner and psychological violence were independently associated with depression after adjusting for socio-economic factors [9]. In a Vietnamese study of a similar design, women exposed to IPV were at a substantially higher risk of memory loss, pain or discomfort, sadness or depression and suicidal thoughts compared to those with no IPV experience in the past year [10].

Rwanda is a low-income country, located in central Africa, with a population of 10.5 million inhabitants and a population density among the highest in Africa (416 inhabitants $/ \mathrm{km}^{2}$ ) [11]. Similar to other low-andmiddle-income countries, non-communicable diseases (NCD) are becoming more and more predominant $[12,13]$. Formerly considered as diseases of the wealthy, NCDs are today competing with infectious diseases in this population, indicating a country in an epidemiological transition phase.

The 2008 update for the Global Burden of Disease Study estimated that non-communicable conditions accounted for $17 \%$ of the disease burden in Rwanda in 2004, of which neuropsychiatric conditions contributed to approximately $4 \%$ [14] while the country was still spending only $1 \%$ of its health budget on mental health [13].

A study from Rwanda investigating the association between IPV and mental disorders, with married men and women, using the Self-Reporting Questionnaire (SRQ-20) to measure common mental disorders and the Revised Conflict Tactics Scale for violence items, indicates that physical violence exposure was associated with common mental disorders and suicidal ideation [15]. Only few studies exist on men's exposure to IPV in Sub-Saharan Africa and there is hardly any study on associated health effects. In our earlier study on IPV prevalence, women are much more exposed to physical, sexual and psychological intimate partner violence than men during past year and earlier in life periods [16].
Furthermore, the Rwandan genocide in 1994, during which about 800.000 people were killed still negatively influences mental health of Rwandan population [17]. As years pass, it becomes more and more evident that there is a considerable degree of psychiatric morbidity as a consequence of serious violent acts inflicted during the Rwandan genocide $[17,18]$. A recent study investigating the trauma exposure related to the Rwandan genocide establish a clear picture of long-term imprints, where a good proportion of the study population was diagnosed with depressive and anxiety symptoms associated with the genocide 17 years later [19].

Prevalence studies on mental health in low income countries are limited while studies on IPV are on the increase; however limited attention has been paid to the association between the two in a population based study including both men and women in post conflict countries.

This study explored the prevalence of mental disorders in a population of young men and women in Rwanda and their risk factors with main emphasis on IPV and its contribution to mental disorders. However, as the Rwandan genocide still causes mental disorders in many Rwandans, the contribution of such exposure was also explored in both men and women.

This study forms part of a larger project on violence and other traumatic episodes, mental health and barriers to care among young men and women, The Rwandan Violence, Mental Health and Barriers to Care project (RwVMHBC-project).

\section{Methods}

\section{Study design, study population and sample size}

A population-based cross-sectional study was conducted on a representative sample of young adults, aged 20 to 35 years, chosen because they represent a large group of the Rwandan population and further, are vulnerable to violence [20] and mental disorders [4]. The sample size was calculated based on the prevalence of depression (20\%) in Rwanda [21], a desired level of absolute precision of $5 \%$ and an estimated design effect of 1.5. In all, 917 households were included. As only one interview was conducted in each household for ethical reasons, the final sample was comprised of 440 men and 477 women with two refusals to participate.

A multi-stage random sampling was used to find households for inclusion in the survey. The selection of villages (the smallest administrative unit in Rwanda), households and study participants in the eight districts of the Southern province of Rwanda was made in three phases. Out of the total number of 3512 existing villages, 35 villages were randomly selected using a random function. The number of households in each village was selected proportionate to the total number of households in each village and the person to be interviewed was 
randomly selected among eligible people in each household i.e. men and women aged between 20 and 35 years. The first participant in each village was selected from the closest household to the center of the village and a calculated sampling interval was applied to get the next household.

\section{Instruments}

To assess the mental health status, four modules from the MINI International Neuropsychiatric interview (DSM-IV) version 5.0.0, were used to identify major depressive episodes in the past two weeks and in earlier periods of 2 week-duration or more, generalized anxiety disorder, suicide risk and post-traumatic stress disorder (PTSD). The MINI is designed as a brief structured interview for diagnosing the major psychiatric disorders according to DSM-IV criteria and International Classification of Diseases-10. Validation studies show that the MINI has similar validity and reliability properties as the WHOCIDI (Composite International Diagnostic Interview for ICD-10) instrument [22]. The advantage with the MINI is that it contains less items, takes less time to administer and can be used by trained interviewers but does not necessarily require clinical staff. To measure physical, sexual and psychological violence exposure, we used the items from the Women's Health and Life experiences questionnaire, developed by WHO [23] and used in several countries all over the world [24]. The questionnaires were translated in Kinyarwanda, one of the national languages in Rwanda.

\section{Data collection procedures}

The data collection took place between December 2011 and January 2012. The School of Public Health, College of Medicine and Health Sciences, University of Rwanda, was the lead implementer of the survey. A pool of experienced interviewers composed of 13 clinical psychologists and two supervisors were recruited. Two-day training was carried out followed by one day for questionnaire piloting. The data entry was performed by four skilled personnel from the Rwanda School of Public Health under the supervision of a data entry manager.

\section{Measurements}

\section{Dependent variables}

Five mental disorders were used as dependent variables: major depressive episodes current (in the 2 weeks preceding the survey), major depressive episodes past (earlier in life periods of two weeks or more), generalized anxiety disorder (in the past six months), suicide risk (anytime in life) and post-traumatic stress disorder current (in the past month) (PTSD).

The major depressive episodes current, generalized anxiety disorder and PTSD sections of the MINI start with two screening questions corresponding to the main criteria of the disorder and end with a diagnostic conclusion indicating whether the criteria was met or not. For suicide risk, consisting of six questions related to symptoms, diagnosis was reached when one was met.

For each mental disorder, the diagnostic conclusion was dichotomized into 'experience' as the exposed category set against 'no experience' as the reference category.

\section{Independent variables}

Physical, sexual and psychological intimate partner violence, traumatic episodes during the genocide period and socio-demographic variables, were analysed as independent risk factors.

Intimate partner violence occurrence was measured by the three forms of violence, physical, sexual and psychological violence in the year preceding the survey. The past year prevalence was measured by assessing acts of physical (6 acts), sexual (3 acts) and psychological (4 acts) violence [16]. The composite measures for physical, sexual and psychological violence respectively were formed and dichotomised into any, as opposed to no violence experience. The 'no violence' category contained persons with no physical, sexual or psychological violence experience.

Age was described as a three category variable (20-24 years, 25-29 years, and 30-35 years), then grouped into 2 categories (20-29 years and 30-35 years) for further analyses. Marital status was divided into married/cohabiting, divorced/widowed and single, later dichotomized as married/cohabiting as the exposed. The Educational level was described as a three group variable (secondary school/university, complete primary/vocational training and incomplete primary); for the bivariate and multivariate analyses; education level was divided into incomplete primary contrasted with higher education. Personal income per month was categorized as a three category variable with more than 35,000Rwf (60USD), between 17,50035,000Rwf (30-60 USD) and less than 17,500Rwf (30 USD) and further, grouped into earning 17,500Rwf or more per month as the reference category and less than 17,500Rwf per month constituted the exposure category. Social support was defined as having a friend or family member that will assist if you become ill, would share food, share housing, lend money, help you with guidance when problems arise and offer support when having personal problems. A composite variable of social support was constructed, grouped into good social support corresponding to, having 'always', 'often' or 'sometimes' the kind of support inquired about, as opposed to poor social support equivalent to the absence of a positive response to any of the support items.

The available assets in the household included a radio, a television set, a refrigerator, a bicycle, a motorcycle, a car, a mobile phone and a computer. The assets were merged and dichotomised into having at least one of the 
items (reference category) versus having none of the items (exposure category). This variable was used as proxy for socio-economic status and having none of the assets inquired about constituted the very poor.

Given the possibility that any existing mental disorder may partly be associated with exposure to any traumatic event during the Rwandan genocide [25], the association between IPV and mental health effects was adjusted for the traumatic episodes during the genocide period. The Traumatic episodes during the genocide period was a summary measure of items of traumatic episodes from the revised versions of Harvard Trauma Questionnaire [26] related to the genocide exposure, dichotomized into "any" as opposed to "no traumatic experience" [27].

\section{Statistical analysis}

Risk factors were estimated with odds ratios (OR) and their 95\% confidence interval (CI) in bi- and multivariate analyses to estimate the association between violence exposure and mental disorders. IBM SPSS Statistics version 20 was used for all descriptive, bivariate and multivariate statistical analyses.

In the multivariate analyses, the final model was created for each mental disorder with each form of violence as the main independent factor. The logistic regression analyses were adjusted for variables proving statistical significance with a majority of mental disorders in the bivariate analyses. For women, these were partner's low education, lack of assets in the household and experience of traumatic episodes during the genocide. For men, the variables controlled for were lack of assets in the household and exposure to traumatic episodes during the genocide period.

The population attributable fraction (PAF) was calculated for men and women respectively to estimate the proportion of mental disorders that were associated with past year IPV. The population attributable fraction of a given mental disorder is thus the proportion of mental disorder in the total study population which could be avoided if no physical, sexual, psychological violence respectively were at hand. It was calculated using a modified formula to account for potential confounding [28,29].

The following formula was used for calculating the PAF: $P A F=P_{e}($ AOR-1) $/($ AOR $)$

Where:

$\mathrm{P}_{\mathrm{e}}=$ proportion with mental disorders who were physically, sexually or psychologically abused.

$\mathrm{AOR}=$ Adjusted odds ratio for the association between IPV and a mental disorder of interest.

\section{Ethical considerations}

The research protocol and tools were approved for scientific and ethical integrity by the Rwanda National Ethics Committee (Review Approval Notice N ${ }^{\circ}$ 165/RNEC/
2011) and the National Institute of Statistics of Rwanda ( $\left.\mathrm{N}^{\mathrm{o}} 1043 / 2011 / 10 / \mathrm{NISR}\right)$. The study strictly followed WHO guidelines on ethical issues related to violenceresearch [30], all participants were informed about their free choice to participate and to withdraw at whatever time they wanted during the study. Interviewers secured written consent from all respondents before the interview. To maintain confidentiality, the interview was conducted in privacy and with one interview in each household. Respondents were informed that questions could be sensitive and were reassured regarding the confidentiality of their responses. As IPV and mental disorders are delicate issues, it was agreed that those in need of any kind of assistance should be taken to a nearby health centre accompanied by the community health worker.

\section{Results}

\section{Socio-demographic and psychosocial factors}

A total of $440(48 \%)$ men and 477 (52\%) women, aged 20 to 35 years were enrolled in the study. The sociodemographic and psychosocial factors in this study reflected the life circumstances in Rwanda, where more than $80 \%$ of the population live in rural areas and approximatively $20 \%$ in urban areas. Only a small proportion of both men and women had completed primary level education (the majority being men) and only a small proportion had a higher income per month, the majority being men (Table 1). Further, a substantial proportion of both men and women had none of the household assets investigated, and hereby were considered extremely poor (26.6\% and $30.6 \%$ respectively). Moreover, most of their partners had almost the same characteristics; a small number had completed primary school or vocational training. The majority of our study population were subsistence farmers, with small incomes and living in rather poor households.

\section{Physical, sexual and psychological intimate partner violence}

Of the participating women, $18.8 \%(n=78)$ had been exposed to physical violence, $17.4 \%(n=71)$ to sexual violence and $21.4 \%(n=92)$ to psychological violence in the past 12 months (Table 1). Compared to women, few men reported intimate partner violence, only $4.3 \% \quad(n=18)$ were victims of physical violence, $1.5 \%(n=6)$ had experienced sexual violence and $7.3 \%(\mathrm{n}=32)$ were victims of psychological violence in the past 12 months. Consequently, there was a statistically significant difference in prevalence for all types of IPV exposure between men and women (Table 1).

\section{Mental disorders}

Women and men suffered from generalized anxiety disorder to about the same extent. Depressive disorders in 
Table 1 Socio-demographic and psychosocial factors for men and women

\begin{tabular}{|c|c|c|c|c|c|c|c|}
\hline \multirow[b]{2}{*}{ Respondents characteristics } & \multicolumn{2}{|c|}{$\begin{array}{l}\text { Total } \\
(\mathrm{N}=917)\end{array}$} & \multicolumn{2}{|c|}{$\begin{array}{l}\text { Men } \\
(n=440)\end{array}$} & \multicolumn{2}{|c|}{$\begin{array}{l}\text { Women } \\
(n=477)\end{array}$} & \multirow[b]{2}{*}{ p-value } \\
\hline & $N$ & $\%$ & $n$ & $\%$ & $n$ & $\%$ & \\
\hline \multicolumn{8}{|l|}{ 1. Age groups in years } \\
\hline $20-24$ & 275 & 30.3 & 148 & 33.8 & 127 & 27.0 & .050 \\
\hline 25-29 & 300 & 33.0 & 144 & 32.9 & 156 & 33.2 & \\
\hline 30-35 & 333 & 36.7 & 146 & 33.3 & 187 & 39.8 & \\
\hline \multicolumn{8}{|l|}{ 2. Marital status } \\
\hline Married or cohabiting & 578 & 63.4 & 236 & 53.8 & 342 & 72.3 & .000 \\
\hline Divorced or widowed & 35 & 3.8 & 2 & 0.5 & 33 & 7.0 & \\
\hline Single & 299 & 32.8 & 201 & 45.8 & 98 & 20.7 & \\
\hline \multicolumn{8}{|l|}{ 3. Level of education } \\
\hline Secondary school or university & 117 & 15.2 & 50 & 13.3 & 67 & 17.0 & .006 \\
\hline Complete primary school or vocational training & 178 & 23.2 & 105 & 28.0 & 73 & 18.6 & \\
\hline Incomplete primary school & 473 & 61.6 & 220 & 58.7 & 253 & 64.4 & \\
\hline \multicolumn{8}{|l|}{ 4. Personal income per month } \\
\hline More than 35,000Rwf & 30 & 3.3 & 19 & 4.3 & 11 & 2.3 & .005 \\
\hline $17,500-35,000$ Rwf & 55 & 6.0 & 36 & 8.2 & 19 & 4.0 & \\
\hline Less than 17,500Rwf & 827 & 90.7 & 382 & 87.4 & 445 & 93.7 & \\
\hline \multicolumn{8}{|l|}{ 5. Social support } \\
\hline Good & 140 & 15.3 & 77 & 17.5 & 63 & 13.2 & .081 \\
\hline Poor & 777 & 84.7 & 363 & 82.5 & 414 & 86.8 & \\
\hline \multicolumn{8}{|l|}{ Partners characteristics } \\
\hline \multicolumn{8}{|l|}{ 6. Partner's age in years } \\
\hline 20-24 & 97 & 16.8 & 67 & 28.2 & 30 & 8.8 & .000 \\
\hline $25-29$ & 170 & 29.5 & 87 & 36.6 & 83 & 24.5 & \\
\hline 30-35 & 310 & 53.7 & 84 & 35.3 & 226 & 66.7 & \\
\hline \multicolumn{8}{|l|}{ 7. Partners' education level } \\
\hline Secondary school or university level & 55 & 11.6 & 21 & 10.0 & 34 & 12.8 & .412 \\
\hline Complete primary school or vocational level & 141 & 29.7 & 59 & 28.1 & 82 & 30.9 & \\
\hline Incomplete primary school & 279 & 58.7 & 130 & 61.9 & 149 & 56.2 & \\
\hline \multicolumn{8}{|l|}{ 8. Assets in the household } \\
\hline Improved (at least one of 8 assets) & 654 & 71.3 & 323 & 73.4 & 331 & 69.4 & .189 \\
\hline Poor (none of the 8 assets) & 263 & 28.7 & 117 & 26.6 & 146 & 30.6 & \\
\hline \multicolumn{8}{|c|}{ Respondents exposure to intimate partner violence } \\
\hline \multicolumn{8}{|l|}{ 9. Physical violence exposure } \\
\hline No & 742 & 88.5 & 404 & 95.7 & 338 & 81.2 & .000 \\
\hline Yes & 96 & 11.5 & 18 & 4.3 & 78 & 18.8 & \\
\hline \multicolumn{8}{|l|}{ 10. Sexual violence exposure } \\
\hline No & 742 & 90.6 & 404 & 98.5 & 338 & 82.6 & .000 \\
\hline Yes & 77 & 9.4 & 6 & 1.5 & 71 & 17.4 & \\
\hline \multicolumn{8}{|l|}{ 11. Psychological violence exposure } \\
\hline No & 742 & 85.7 & 404 & 92.7 & 338 & 78.6 & .000 \\
\hline Yes & 124 & 14.3 & 32 & 7.3 & 92 & 21.4 & \\
\hline
\end{tabular}

*p-value signifies statistical difference between men and women. 
the past two weeks and in earlier periods were more than two times more common in women than in men (women $26.5 \%$, men $12.1 \%$, and women $23.3 \%$, men $8.4 \%$, respectively). Similarly, suicide risk and PTSD cases were more than two times more common in women than in men (women $21.8 \%$, men $9.6 \%$ and women: $19.6 \%$ and $7.1 \%$ respectively) (Table 2).

Associations between IPV and mental disorders in women Bivariate associations revealed that, for women, exposure to physical, sexual and psychological IPV considerably increased the risk of all the mental disorders explored in this study. Physical violence as well as psychological abuse were highly associated with major depressive episode in the past two weeks (OR 4.67, 2.77-7.87 and OR $4.84 ; 2.96-7.92$ respectively), while sexual abuse were highly associated with generalised anxiety disorder (OR 5.31; 3.04-9.30) (Table 3).

For women exposed to physical violence, the multivariate analyses showed that there was no change in odds ratios for depression in the past two weeks, for depression in earlier periods or for generalized anxiety disorder after controlling for socio-demographic and psychosocial variables (Table 3). Thus, the risk of depression in the past two weeks for women exposed to physical violence was more than four times higher (OR 4.63, 2.57-8.32) compared to unexposed women while exposure to sexual and psychological abuse gave adjusted odds ratios of 5.49 (2.94-10.25) and 5.59 (3.19-9.80) respectively compared to women unexposed to IPV. Additionally, physical, sexual and psychological violence remained statistically significant risk factors for suicide risk and PTSD, exhibiting slightly elevated odds ratios in the final models (Table 3).

Of interest is also to note that of the socio-demographic factors investigated in the multivariate analyses, partner's low education and lack of assets in the household (as a proxy of socio-economic status) contributed to the risk of current and earlier depression. Similarly, partner's education remained as a statistically significant risk factor for generalized anxiety disorder. Traumatic episodes that occurred 17 years earlier contributed significantly to the risk of PTSD, generalized anxiety disorder and suicide risk.

\section{Associations between IPV and mental disorders for men}

The bivariate analyses showed that past year physical and psychological violence were highly associated with current major depressive episodes (OR 5.47, 2.01-14.87), earlier major depressive episodes (OR 3.54, 1.10-11.44) and generalized anxiety disorder for men (Table 4). After controlling for lack of assets in the household and exposure to traumatic episodes during the genocide period, past year physical and psychological violence remained a statistically significant risk factor for depression in the past two weeks (OR 4.17, 1.46-11.91 and 3.53, 1.548.08). Physical and psychological violence exposure also constituted statistically significant risk factors of magnitude for generalized anxiety disorder (OR 6.58, 2.0820.81 and $4.19,1.90-9.26)$ but not for earlier depressive episode when controlling for the same variables.

Table 2 Prevalence of mental disorders for men and women

\begin{tabular}{|c|c|c|c|c|c|c|c|}
\hline \multirow[t]{2}{*}{ Mental disorders } & \multicolumn{2}{|c|}{$\begin{array}{l}\text { Total population } \\
\mathrm{N}=917\end{array}$} & \multicolumn{2}{|c|}{$\begin{array}{l}\text { Men } \\
n=440\end{array}$} & \multicolumn{2}{|c|}{$\begin{array}{l}\text { Women } \\
n=477\end{array}$} & \multirow[b]{2}{*}{ p-value* } \\
\hline & $n$ & $\%$ & $n$ & $\%$ & $n$ & $\%$ & \\
\hline \multicolumn{8}{|c|}{ 1. Major depressive episodes in the past two weeks } \\
\hline No & 736 & 80.4 & 386 & 87.9 & 350 & 73.5 & .000 \\
\hline Yes & 179 & 19.6 & 53 & 12.1 & 126 & 26.5 & \\
\hline \multicolumn{8}{|c|}{ 2. Major depressive episodes in earlier periods, of two weeks or more } \\
\hline No & 764 & 83.9 & 401 & 91.6 & 363 & 76.7 & .000 \\
\hline Yes & 147 & 16.1 & 37 & 8.4 & 110 & 23.3 & \\
\hline \multicolumn{8}{|l|}{ 3. Suicide risk } \\
\hline No & 769 & 84.0 & 396 & 90.4 & 373 & 78.2 & .000 \\
\hline Yes & 146 & 16.0 & 42 & 9.6 & 104 & 21.8 & \\
\hline \multicolumn{8}{|c|}{ 4. Post-Traumatic Stress Disorder (PTSD) } \\
\hline No & 789 & 86.4 & 407 & 92.9 & 382 & 80.4 & .000 \\
\hline Yes & 124 & 13.6 & 31 & 7.1 & 93 & 19.6 & \\
\hline \multicolumn{8}{|c|}{ 5. Generalized anxiety Disorder } \\
\hline No & 580 & 63.5 & 292 & 66.5 & 288 & 60.8 & .074 \\
\hline Yes & 333 & 36.5 & 147 & 33.5 & 186 & 39.2 & \\
\hline
\end{tabular}

*p-value signifies statistical difference between men and women. 
Table 3 Associations between physical, sexual and psychological violence and mental disorders in women $(\mathrm{N}=477)$

\begin{tabular}{|c|c|c|c|c|c|c|c|c|c|c|c|c|c|c|c|}
\hline \multirow[t]{4}{*}{ Variables } & \multicolumn{3}{|c|}{$\begin{array}{l}\text { Major depressive episode } \\
\text { in the past two weeks }\end{array}$} & \multicolumn{3}{|c|}{$\begin{array}{l}\text { Major depressive episode } \\
\text { in earlier periods }\end{array}$} & \multicolumn{3}{|c|}{ Generalized anxiety disorder } & \multicolumn{3}{|c|}{ Suicide risk } & \multicolumn{3}{|c|}{ Post-traumatic stress disorder } \\
\hline & \multirow{3}{*}{$\begin{array}{l}\text { n } \\
(\%)\end{array}$} & \multirow{3}{*}{$\begin{array}{l}\text { Crude OR } \\
\text { OR } \\
(95 \% \mathrm{Cl})\end{array}$} & \multirow{3}{*}{$\begin{array}{l}\text { Adjusted OR } \\
\text { OR } \\
(95 \% \mathrm{Cl})\end{array}$} & \multirow{3}{*}{$\begin{array}{l}n \\
\text { (\%) }\end{array}$} & \multirow{3}{*}{$\begin{array}{l}\text { Crude OR } \\
\text { OR } \\
(95 \% \mathrm{Cl})\end{array}$} & \multirow{3}{*}{$\begin{array}{l}\text { Adjusted OR } \\
\text { OR } \\
(95 \% \mathrm{Cl})\end{array}$} & \multirow{3}{*}{$\begin{array}{l}\text { n } \\
(\%)\end{array}$} & \multirow{3}{*}{$\begin{array}{l}\text { Crude OR } \\
\text { OR } \\
(95 \% \mathrm{Cl})\end{array}$} & \multirow{3}{*}{$\begin{array}{l}\text { Adjusted OR } \\
\text { OR } \\
(95 \% \mathrm{Cl})\end{array}$} & \multirow{3}{*}{$\begin{array}{l}\mathrm{n} \\
\text { (\%) }\end{array}$} & \multirow{3}{*}{$\begin{array}{l}\text { Crude OR } \\
\text { OR } \\
(95 \% \mathrm{Cl})\end{array}$} & \multirow{3}{*}{$\begin{array}{l}\text { Adjusted OR } \\
\text { OR } \\
(95 \% \mathrm{Cl})\end{array}$} & \multirow{3}{*}{$\begin{array}{l}\text { n (\%) } \\
\text { n } \\
(\%)\end{array}$} & \multirow{3}{*}{$\begin{array}{l}\text { Crude OR } \\
\text { OR } \\
(95 \% \mathrm{Cl})\end{array}$} & \multirow{3}{*}{$\begin{array}{l}\text { Adjusted OR } \\
\text { OR } \\
(95 \% \mathrm{Cl})\end{array}$} \\
\hline & & & & & & & & & & & & & & & \\
\hline & & & & & & & & & & & & & & & \\
\hline Physical violence & $\begin{array}{l}40 \\
(51.3)\end{array}$ & $\begin{array}{l}4.67 \\
(2.77-7.87)\end{array}$ & $\begin{array}{l}4.63 \\
(2.57-8.32)\end{array}$ & $\begin{array}{l}33 \\
(42.9)\end{array}$ & $\begin{array}{l}3.44 \\
(2.02-5.85)\end{array}$ & $\begin{array}{l}2.88 \\
(1.59-5.23)\end{array}$ & $\begin{array}{l}51 \\
(66.2)\end{array}$ & $\begin{array}{l}4.38 \\
(2.59-7.40)\end{array}$ & $\begin{array}{l}4.70 \\
(2.65-8.35)\end{array}$ & $\begin{array}{l}33 \\
(42.3)\end{array}$ & $\begin{array}{l}3.62 \\
(2.12-6.15)\end{array}$ & $\begin{array}{l}4.54 \\
(2.49-8.27)\end{array}$ & $\begin{array}{l}26 \\
(33.3)\end{array}$ & $\begin{array}{l}2.79 \\
(1.60-4.88)\end{array}$ & $\begin{array}{l}3.16 \\
(1.67-5.95)\end{array}$ \\
\hline Partners' education & & & $\begin{array}{l}2.47 \\
(1.33-4.55)\end{array}$ & & & $\begin{array}{l}2.94 \\
(1.55-5.56)\end{array}$ & & & $\begin{array}{l}1.79 \\
(1.07-2.98)\end{array}$ & & & $\begin{array}{l}1.06 \\
(0.59-1.92)\end{array}$ & & & $\begin{array}{l}1.27 \\
(0.68-2.38)\end{array}$ \\
\hline Assets in the household & & & $\begin{array}{l}2.33 \\
(1.31-4.13)\end{array}$ & & & $\begin{array}{l}2.25 \\
(1.27-4.00)\end{array}$ & & & $\begin{array}{l}1.25 \\
(0.74-2.14)\end{array}$ & & & $\begin{array}{l}0.96 \\
(0.52-1.79)\end{array}$ & & & $\begin{array}{l}0.98 \\
(0.51-1.89)\end{array}$ \\
\hline $\begin{array}{l}\text { Traumatic experience } \\
\text { during the genocide }\end{array}$ & & & $\begin{array}{l}1.56 \\
(0.88-2.75)\end{array}$ & & & $\begin{array}{l}1.40 \\
(0.79-2.48)\end{array}$ & & & $\begin{array}{l}1.72 \\
(1.04-2.83)\end{array}$ & & & $\begin{array}{l}1.68 \\
(0.95-2.98)\end{array}$ & & & $\begin{array}{l}2.02 \\
(1.10-3.70)\end{array}$ \\
\hline Sexual violence & $\begin{array}{l}37 \\
(52.1)\end{array}$ & $\begin{array}{l}4.83 \\
(2.81-8.29)\end{array}$ & $\begin{array}{l}5.49 \\
(2.94-10.25)\end{array}$ & $\begin{array}{l}27 \\
(38.6)\end{array}$ & $\begin{array}{l}2.88 \\
(1.65-5.02)\end{array}$ & $\begin{array}{l}2.74 \\
(1.45-5.15)\end{array}$ & $\begin{array}{l}50 \\
(70.4)\end{array}$ & $\begin{array}{l}5.31 \\
(3.04-9.30)\end{array}$ & $\begin{array}{l}6.37 \\
(3.45-11.79)\end{array}$ & $\begin{array}{l}26 \\
(36.6)\end{array}$ & $\begin{array}{l}2.85 \\
(1.63-4.99)\end{array}$ & $\begin{array}{l}3.73 \\
(2.00-6.95)\end{array}$ & $\begin{array}{l}25 \\
(35.2)\end{array}$ & $\begin{array}{l}3.04 \\
(1.72-5.38)\end{array}$ & $\begin{array}{l}4.20 \\
(2.22-7.95)\end{array}$ \\
\hline Partners' education & & & $\begin{array}{l}2.15 \\
(1.15-4.02)\end{array}$ & & & $\begin{array}{l}2.51 \\
(1.32-4.77)\end{array}$ & & & $\begin{array}{l}1.50 \\
(0.89-2.54)\end{array}$ & & & $\begin{array}{l}1.06 \\
(0.58-1.96)\end{array}$ & & & $\begin{array}{l}0.92 \\
(0.49-1.73)\end{array}$ \\
\hline Assets in the household & & & $\begin{array}{l}2.66 \\
(1.47-4.84)\end{array}$ & & & $\begin{array}{l}2.46 \\
(1.36-4.45)\end{array}$ & & & $\begin{array}{l}1.45 \\
(0.83-2.52)\end{array}$ & & & $\begin{array}{l}1.55 \\
(0.83-2.92)\end{array}$ & & & $\begin{array}{l}1.11 \\
(0.57-2.17)\end{array}$ \\
\hline $\begin{array}{l}\text { Traumatic experience } \\
\text { during the genocide }\end{array}$ & & & $\begin{array}{l}1.92 \\
1.06-3.47)\end{array}$ & & & $\begin{array}{l}1.61 \\
0.89-2.91)\end{array}$ & & & $\begin{array}{l}1.91 \\
(1.14-3.20)\end{array}$ & & & $\begin{array}{l}1.80 \\
(0.99-3.26)\end{array}$ & & & $\begin{array}{l}1.86 \\
(1.01-3.45)\end{array}$ \\
\hline Psychological violence & $\begin{array}{l}48 \\
(52.2)\end{array}$ & $\begin{array}{l}4.84 \\
(2.96-7.92)\end{array}$ & $\begin{array}{l}5.59 \\
(3.19-9.80)\end{array}$ & $\begin{array}{l}37 \\
(40.7)\end{array}$ & $\begin{array}{l}3.14 \\
(1.90-5.19)\end{array}$ & $\begin{array}{l}2.95 \\
(1.66-5.21)\end{array}$ & $\begin{array}{l}57 \\
(62.6)\end{array}$ & $\begin{array}{l}3.74 \\
(2.31-6.07)\end{array}$ & $\begin{array}{l}4.34 \\
(2.54-7.43)\end{array}$ & $\begin{array}{l}39 \\
(42.4)\end{array}$ & $\begin{array}{l}3.63 \\
(2.20-5.99)\end{array}$ & $\begin{array}{l}4.22 \\
(2.37-7.49)\end{array}$ & $\begin{array}{l}29 \\
(31.5)\end{array}$ & $\begin{array}{l}2.57 \\
(1.51-4.38)\end{array}$ & $\begin{array}{l}2.97 \\
(1.62-5.45)\end{array}$ \\
\hline Partners' education & & & $\begin{array}{l}1.80 \\
(1.00-3.24)\end{array}$ & & & $\begin{array}{l}2.61 \\
(1.40-4.88)\end{array}$ & & & $\begin{array}{l}1.54 \\
(0.93-2.55)\end{array}$ & & & $\begin{array}{l}1.06 \\
(0.59-1.91)\end{array}$ & & & $\begin{array}{l}1.11 \\
(0.59-2.06)\end{array}$ \\
\hline Assets in the household & & & $\begin{array}{l}2.44 \\
(1.39-4.28)\end{array}$ & & & $\begin{array}{l}2.53 \\
(1.45-4.44)\end{array}$ & & & $\begin{array}{l}1.30 \\
(0.77-2.20)\end{array}$ & & & $\begin{array}{l}1.35 \\
(0.74-2.46)\end{array}$ & & & $\begin{array}{l}1.44 \\
(0.77-2.69)\end{array}$ \\
\hline $\begin{array}{l}\text { Traumatic experience } \\
\text { during the genocide }\end{array}$ & & & $\begin{array}{l}1.34 \\
(0.77-2.32)\end{array}$ & & & $\begin{array}{l}1.43 \\
(0.82-2.50)\end{array}$ & & & $\begin{array}{l}1.57 \\
(0.96-2.56)\end{array}$ & & & $\begin{array}{l}1.96 \\
(1.12-3.42)\end{array}$ & & & $\begin{array}{l}1.87 \\
(1.04-3.38)\end{array}$ \\
\hline
\end{tabular}


Table 4 Associations between physical and psychological violence and mental disorders for men $(\mathrm{N}=440)$

\begin{tabular}{|c|c|c|c|c|c|c|c|c|c|c|c|c|c|c|c|}
\hline \multirow[t]{4}{*}{ Variables } & \multicolumn{3}{|c|}{$\begin{array}{l}\text { Major depressive episode } \\
\text { in the past } 2 \text { weeks }\end{array}$} & \multicolumn{3}{|c|}{$\begin{array}{l}\text { Major depressive episode } \\
\text { in earlier periods }\end{array}$} & \multicolumn{3}{|c|}{ Generalized anxiety disorder } & \multicolumn{3}{|c|}{ Suicide risk } & \multicolumn{3}{|c|}{ Post-traumatic stress disorder } \\
\hline & & Crude OR & $\begin{array}{l}\text { Adjusted } \\
\text { OR }\end{array}$ & & Crude OR & $\begin{array}{l}\text { Adjusted } \\
\text { OR }\end{array}$ & & Crude OR & $\begin{array}{l}\text { Adjusted } \\
\text { OR }\end{array}$ & & $\begin{array}{l}\text { Crude } \\
\text { OR }\end{array}$ & $\begin{array}{l}\text { Adjusted } \\
\text { OR }\end{array}$ & & $\begin{array}{l}\text { Crude } \\
\text { OR }\end{array}$ & $\begin{array}{l}\text { Adjusted } \\
\text { OR }\end{array}$ \\
\hline & $\mathrm{n}$ & OR & OR & $\mathrm{n}$ & OR & OR & $\mathrm{n}$ & OR & OR & $\mathrm{n}$ & OR & OR & $\mathbf{n}$ & OR & OR \\
\hline & (\%) & (95\% Cl) & $(95 \% \mathrm{Cl})$ & (\%) & $(95 \% \mathrm{Cl})$ & $(95 \% \mathrm{Cl})$ & (\%) & $(95 \% \mathrm{Cl})$ & $(95 \% \mathrm{Cl})$ & $(\%)$ & $(95 \% \mathrm{Cl})$ & $(95 \% \mathrm{Cl})$ & (\%) & $(95 \% \mathrm{Cl})$ & (95\% Cl) \\
\hline Physical violence & $\begin{array}{l}7 \\
(38.9)\end{array}$ & $\begin{array}{l}5.47 \\
(2.01-14.87)\end{array}$ & $\begin{array}{l}4.17 \\
(1.46-11.91)\end{array}$ & $\begin{array}{l}4 \\
(22.2)\end{array}$ & $\begin{array}{l}3.54 \\
(1.10-11.44)\end{array}$ & $\begin{array}{l}2.09 \\
(0.60-7.30)\end{array}$ & $\begin{array}{l}14 \\
(77.8)\end{array}$ & $\begin{array}{l}7.88 \\
(2.54-24.41)\end{array}$ & $\begin{array}{l}6.58 \\
(2.08-20.81)\end{array}$ & $\begin{array}{l}3 \\
(16.7)\end{array}$ & $\begin{array}{l}1.97 \\
(0.55-7.13)\end{array}$ & $\begin{array}{l}1.44 \\
(0.38-5.40)\end{array}$ & $\begin{array}{l}2 \\
(11.1)\end{array}$ & $\begin{array}{l}1.74 \\
(0.38-7.95)\end{array}$ & $\begin{array}{l}1.45 \\
(0.31-6.81)\end{array}$ \\
\hline $\begin{array}{l}\text { Assets in the } \\
\text { household }\end{array}$ & & & $\begin{array}{l}2.23 \\
(1.19-4.20)\end{array}$ & & & $\begin{array}{l}2.60 \\
(1.24-5.44)\end{array}$ & & & $\begin{array}{l}1.64 \\
(1.03-2.61)\end{array}$ & & & $\begin{array}{l}1.73 \\
(0.87-3.44)\end{array}$ & & & $\begin{array}{l}1.25 \\
(0.55-2.84)\end{array}$ \\
\hline $\begin{array}{l}\text { Traumatic experience } \\
\text { during the genocide }\end{array}$ & & & $\begin{array}{l}2.05 \\
(1.10-3.83)\end{array}$ & & & $\begin{array}{l}4.40 \\
(2.01-9.63)\end{array}$ & & & $\begin{array}{l}1.83 \\
(1.19-2.81)\end{array}$ & & & $\begin{array}{l}2.18 \\
(1.12-4.25)\end{array}$ & & & $\begin{array}{l}1.62 \\
(0.75-3.49)\end{array}$ \\
\hline Psychological violence & $\begin{array}{l}11 \\
(34.4)\end{array}$ & $\begin{array}{l}4.50 \\
(2.03-9.98)\end{array}$ & $\begin{array}{l}3.53 \\
(1.54-8.08)\end{array}$ & $\begin{array}{l}7 \\
(21.9)\end{array}$ & $\begin{array}{l}3.47 \\
(1.39-8.69)\end{array}$ & $\begin{array}{l}2.36 \\
(0.89-6.21)\end{array}$ & $\begin{array}{l}22 \\
(68.8)\end{array}$ & $\begin{array}{l}4.99 \\
(2.29-10.84)\end{array}$ & $\begin{array}{l}4.19 \\
(1.90-9.26)\end{array}$ & $\begin{array}{l}5 \\
(15.6)\end{array}$ & $\begin{array}{l}1.83 \\
(0.66-5.03)\end{array}$ & $\begin{array}{l}1.39 \\
(0.49-3.95)\end{array}$ & $\begin{array}{l}4 \\
(12.5)\end{array}$ & $\begin{array}{l}1.98 \\
(0.65-6.07)\end{array}$ & $\begin{array}{l}1.83 \\
(0.58-5.74)\end{array}$ \\
\hline $\begin{array}{l}\text { Assets in the } \\
\text { household }\end{array}$ & & & $\begin{array}{l}1.89 \\
(1.03-3.49)\end{array}$ & & & $\begin{array}{l}1.97 \\
(0.96-4.03)\end{array}$ & & & $\begin{array}{l}1.49 \\
(0.95-2.35)\end{array}$ & & & $\begin{array}{l}1.67 \\
(0.85-3.28)\end{array}$ & & & $\begin{array}{l}1.04 \\
(0.46-2.36)\end{array}$ \\
\hline $\begin{array}{l}\text { Traumatic experience } \\
\text { during the genocide }\end{array}$ & & & $\begin{array}{l}1.98 \\
(1.09-3.59)\end{array}$ & & & $\begin{array}{l}3.62 \\
(1.74-7.52)\end{array}$ & & & $\begin{array}{l}1.80 \\
(1.18-2.73)\end{array}$ & & & $\begin{array}{l}2.10 \\
(1.10-4.03)\end{array}$ & & & $\begin{array}{l}1.36 \\
(0.64-2.87)\end{array}$ \\
\hline
\end{tabular}


Physical and psychological violence did not remain statistically significant risk factors for suicide risk or PTSD when the analyses were adjusted for assets in the household and traumatic episodes in the genocide period.

Similarly for men, lack of assets in the household, i.e. extreme poverty contributed to the risk of depression, current and earlier as well as generalized anxiety disorder while having experienced traumatic episodes during the genocide contributed significantly to the risk of all mental disorders investigated except PTSD (Table 4).

\section{Population attributable fraction}

The population attributable fraction (PAF) was used to calculate the contribution of physical, sexual and psychological violence to mental disorders for women and men.

If IPV could be eliminated among exposed women and men, the prevalence of serious mental disorders would be considerably decreased. For instance, for women, if physical and sexual violence were eliminated, generalized anxiety disorder would be reduced by $52 \%$ and $59 \%$ respectively. Likewise, for men, if physical and psychological violence were eliminated, generalized anxiety disorders would be reduced by $55 \%$ and $44 \%$ respectively (Table 5 ).

\section{Discussion}

This study provides important findings on the prevalence of mental disorders among young Rwandan men and women and the considerable contribution made by all forms of IPV to mental disorders in both men and women. The risk of current major depressive episodes, generalized anxiety disorder and suicide risk was more than three times elevated in women exposed to physical, sexual or psychological partner abuse as compared to women not exposed to any form of partner abuse. Furthermore, the population attributable fractions of intimate partner violence to mental disorders were high. Although men were considerably less exposed than women to violence exercised by the partner, they anyway suffered the risk of current major depressive episodes and generalized anxiety disorder when exposed to either physical or psychological abuse. These results are consistent with previous findings $[7,10,15]$.

Other factors that seriously affected men's and women's mental health were poverty (lack of assets in the household) and experience of traumatic episodes in the genocide period, even though 17 years have elapsed since then. Partner's poor educational attainment also contributed to mental disorders in women.

\section{Mental disorders in women}

The general high prevalence of mental disorders in young women in this study, in which about one quarter suffered from major depressive episodes, generalized anxiety disorder, suicide risk and about one fifth from PTSD, reflects the numerous stressors in women's everyday life. Our finding that women are at risk of carrying the double burden of IPV and poverty, causing additional stress, depression and other mental disorders is similarly found in other studies $[5,31]$. From Rwanda, high rates of mental disorders including depression and PTSD are reported to be associated with traumatic episodes during the genocide $[21,25]$, which was also found in this study. Other studies from the post conflict settings further indicate that exposure to war related violence has well established associations with mental disorders including depression and PTSD [32-34].

For women, although adjustments were made for factors evidenced to be associated with mental health and particularly related to the Rwandan genocide exposure, associations between IPV and mental disorders in our study were convincing and in this way corroborate with findings from other low and middle income countries [8,35-37]. A recent review and a number of studies have further shown that depression, PTSD, suicide and anxiety are the most prevalent mental disorders related to IPV $[5,36,38,39]$. However, even if suicide risk was not the most prevalent disorder in our study but detected in one woman out of five, it needs further attention, as in some cases it might result in a suicide. Strong associations between all forms

Table 5 Population attributable fractions calculated for violence exposure and mental disorders as outcome variables for women and men

\begin{tabular}{|c|c|c|c|c|c|c|}
\hline & \multicolumn{6}{|c|}{ Proportion of the outcome attributable to the exposure for women, $\mathrm{N}=477$} \\
\hline & & $\begin{array}{l}\text { Major depressive episodes } \\
\text { past two weeks }\end{array}$ & $\begin{array}{l}\text { Major depressive episodes } \\
\text { in earlier periods }\end{array}$ & Suicide risk & PTSD & Generalized anxiety disorder \\
\hline \multirow[t]{7}{*}{ Exposure } & Physical violence & 0.40 & 0.28 & 0.33 & 0.23 & 0.52 \\
\hline & Sexual violence & 0.43 & 0.25 & 0.27 & 0.27 & 0.59 \\
\hline & Psychological violence & 0.43 & 0.27 & 0.32 & 0.21 & 0.48 \\
\hline & \multicolumn{6}{|c|}{ Proportion of the outcome attributable to the exposure for men, $N=440$} \\
\hline & & $\begin{array}{l}\text { Major depressive episodes } \\
\text { past two weeks }\end{array}$ & $\begin{array}{l}\text { Major depressive episodes } \\
\text { in earlier periods }\end{array}$ & Suicide risk & PTSD & Generalized anxiety disorder \\
\hline & Physical violence & 0.23 & 0.07 & 0.04 & 0.03 & 0.55 \\
\hline & Psychological violence & 0.19 & 0.09 & 0.03 & 0.05 & 0.44 \\
\hline
\end{tabular}


of violence and suicidal thoughts have been found in other studies using the WHO questionnaire $[10,40]$.

Despite that IPV had strong associations with all forms of mental disorders, the partner's low educational attainment and poverty (few assets in the household) similarly contributed to major depressive episode in the past two weeks and earlier, while traumatic experience in the genocide period was primarily associated with PTSD and suicide risk.

\section{Mental disorders in men}

Our findings indicate that men suffer from mental disorders but to a lower degree than women, and IPV exposure was also lower compared to women. Few previous studies have included men in exploring the health effects of intimate partner violence and these are mainly from high income countries [41-43]. One of these studies, found no evidence of an association between IPV exposure and suicide attempts in men [42]. Another study reports that associations were at hand between IPV exposure and mental disorders, mainly with depressive symptoms [44] as did our findings. In our study, other factors, such as exposure to traumatic episodes during the genocide period and poverty were important risk factors for most of mental disorders for men in this study.

\section{The contribution of physical, sexual and psychological violence to mental disorders}

As the population attributable fraction calculations indicated, any form of IPV has serious influence particularly on women's mental health. Any strategy to improve women's empowerment would possibly reduce the prevalence of mental disorders and in a longer perspective, the prevalence of IPV. A microfinance programme (loans) combined with a gender training intervention has been successful in other settings [45].

\section{Methodological considerations}

This study randomly selected its population in a representative sample of young men and women in the southern province of Rwanda. A validated diagnostic tool for mental disorders and a well acknowledged, validated instrument for intimate partner violence were used. Interviews were performed by clinical psychologists with a good experience of scientific interviewing. The strength of this study is also the possibility to include exposure to traumatic episodes during the genocide period as an independent risk factor as several articles in the field from different post conflict areas have illustrated its long term impact on mental health status in men and women. For women, we hereby were able to show that partner violence was a strong independent risk factor also when the traumatic episodes during the genocide period variable was added to the analyses.

The variable 'assets in the household' was used as a proxy for socio-economic status as incomes were extremely small and the majority of the households had no regular income. Such estimates similarly have been used in the demographic health surveys undertaken in 2005 and in 2010 in Rwanda. However, this was a cross-sectional study, which limits interpretation of findings in relation to the direction of the association between IPV and mental disorders. However, a review article based on longitudinal studies provides considerable evidence to support the theory that a history of intimate partner violence precedes poor mental health outcome [5]. Additionally, under-reporting of intimate partner violence and mental disorders may be at hand due to their delicate nature and, the fear of disclosing such experiences. We believe that our results are most probably not overestimated.

\section{Conclusion}

A life free of violence is a basic human right that every woman, man and child deserves. However, IPV is still a major contributing factor to mental disorders, especially in women. Given the high population attributable fraction, the prevention of IPV should be a public health priority as its prevention would contribute substantially to a reduction in mental disorders. Prevention activities have to challenge present social norms that support male authority and control over women. Gender equality and women's empowerment need to be strengthened. Access to paid employment for both men and women would bring families out of poverty, improve women's status and independence and possibly also reduce violence and mental disorders in families.

\section{Abbreviations}

IPV: Intimate partner violence; MINI: Mini International Neuropsychiatric Interview; PTSD: Post traumatic stress disorders; PAF: Population attributable fraction; NCD: Non-communicable diseases; RwMHBC project: The Rwanda Violence, Mental Health and Barriers to Care project; SPH: School of Public Health; RNEC: Rwanda National Ethic Committee; NISR: National Institute of Statistics of Rwanda; WHO: World Health Organization.

\section{Competing interests}

The authors declare that they have no conflicts of interest.

\section{Authors' contributions}

GK designed the project. The study questionnaire was developed by GK, IM, JN and complemented by AU. AU developed the study methodology, led the data

collection activities, made all the statistical analyses and drafted the manuscript. All authors ( $\mathrm{AU}, \mathrm{IM}, \mathrm{JN}$, and $\mathrm{GK}$ ) read and approved the final content of the manuscript.

\section{Acknowledgements}

This study forms part of the Rwanda Violence, Mental Health and Barriers to Care project (RwVMHBC), a collaborative project between University of Rwanda, School of Public Health and Department of Public Health and Community Medicine, University of Gothenburg, Sweden and supported by a grant from The Swedish International Development Cooperation Agency, SIDA.

We would like to acknowledge the men and women who participated in the study, and who gave their valuable time to answer our questions and share their life experiences with us. We gratefully thank interviewers, field supervisors and others for their participation in the study. We are additionally grateful to the Department of Public Health and Community Medicine at Gothenburg University and the School of Public Health, College of Medicine and Health Sciences, University of Rwanda for all the support given to the project. 


\section{Copyright}

The MINI was reproduced with the permission of copyright holder,

(c) Copyright 1994-2010 Sheenan DV \& Lecrubier Y.

\section{Author details}

'Department of Epidemiology and Biostatistics, School of Public health, College of Medicine and Health Sciences, University of Rwanda, Kigali, Rwanda. ${ }^{2}$ Department of Public Health and Community Medicine, Sahlgrenska Academy at Gothenburg University, Gothenburg, Sweden. ${ }^{3}$ Department of Clinical Sciences, Obstetrics and Gynecology, Umea University, Umea, Sweden.

Received: 4 March 2014 Accepted: 24 October 2014

Published online: 18 November 2014

\section{References}

1. The World Health Report on Mental Health: New Understanding, New Hope [http://www.who.int/whr/2001/en/whr01_en.pdf]

2. Prince M, Patel V, Saxena S, Maj M, Maselko J, Phillips MR, Rahman A: No health without mental health. Lancet 2007, 370(9590):859-877.

3. McBain R, Norton DJ, Morris J, Yasamy MT, Betancourt TS: The role of health systems factors in facilitating access to psychotropic medicines: a cross-sectional analysis of the WHO-AIMS in 63 low- and middle-income countries. PLoS Med 2012, 9(1):e1001166.

4. Global and regional estimates of violence against women: prevalence and health effects of intimate partner violence and non-partner sexual violence [http://www.who.int/reproductivehealth/publications/violence/ 9789241564625/en/index.html]

5. Dillon G, Hussain R, Loxton D, Rahman S: Mental and Physical Health and Intimate Partner Violence against Women: A Review of the Literature. Int J Family Med 2013, 2013:313909.

6. Vos T, Astbury J, Piers LS, Magnus A, Heenan M, Stanley L, Walker L, Webster $K$ : Measuring the impact of intimate partner violence on the health of women in Victoria, Australia. Bull World Health Organ 2006, 84(9):739-744.

7. Ali TS, Mogren I, Krantz G: Intimate Partner Violence and Mental Health Effects: A Population-Based Study among Married Women in Karachi, Pakistan. Int J Behav Med 2013, 20(1):131-139.

8. Mahenge B, Likindikoki S, Stockl H, Mbwambo J: Intimate partner violence during pregnancy and associated mental health symptoms among pregnant women in Tanzania: a cross-sectional study. BJOG 2013, 120(8):940-946.

9. Deyessa N, Berhane Y, Alem A, Ellsberg M, Emmelin M, Hogberg U, Kullgren G: Intimate partner violence and depression among women in rural Ethiopia: a cross-sectional study. Clin Pract Epidemiol Ment Health 2009, 5:8

10. Vung ND, Ostergren PO, Krantz G: Intimate partner violence against women, health effects and health care seeking in rural Vietnam. Eur $J$ Public Health 2009, 19(2):178-182.

11. Rwanda National Institute of Statistics. Characteristics of households and housing census, Rwanda, 2012. [http://www.Imis.gov.rw/scripts/publication/ reports/Fourth\%20Rwanda\%20Population\%20and\%20Housing\% 20Census_Housing.pdf]

12. Lopez AD, Project DCP: Global burden of disease and risk factors. New York, NY: Oxford University Press; 2006.

13. World Health Organization: Mental Health Atlas; 2005:395-396. http://www who.int/mental_health/evidence/atlas/profiles_countries_n_r1.pdf?ua=1.

14. Mathers C, Boerma T, Fat DM: World Health Organization. Geneva: The Global Burden of Disease, 2004 Update; 2008.

15. Verduin F, Engelhard EA, Rutayisire T, Stronks K, Scholte WF: Intimate Partner Violence in Rwanda: The Mental Health of Victims and Perpetrators. J Interpers Violence 2012, 28(9):1839-1858. doi:10.1177/ 0886260512469106.

16. Umubyeyi A, Mogren I, Ntaganira J, Krantz G: Women are considerably more exposed to intimate partner violence than men in Rwanda: results from a population-based, cross-sectional study. BMC Womens Health 2014, 14:99.

17. Munyandamutsa N, Mahoro Nkubamugisha P, Gex-Fabry M, Eytan A: Mental and physical health in Rwanda 14 years after the genocide. Soc Psychiatry Psychiatr Epidemiol 2012, 47(11):1753-1761.

18. Schaal S, Weierstall $R$, Dusingizemungu JP, Elbert T: Mental health 15 years after the killings in Rwanda: imprisoned perpetrators of the genocide against the Tutsi versus a community sample of survivors. J Trauma Stress 2012, 25(4):446-453.
19. Rieder H, Elbert T: Rwanda - lasting imprints of a genocide: trauma, mental health and psychosocial conditions in survivors, former prisoners and their children. Confl Health 2013, 7(1):6.

20. Ntaganira J, Muula AS, Masaisa F, Dusabeyezu F, Siziya S, Rudatsikira E: Intimate partner violence among pregnant women in Rwanda. BMC Womens Health 2008, 8:17.

21. Bolton P, Neugebauer R, Ndogoni L: Prevalence of depression in rural Rwanda based on symptom and functional criteria. J Nerv Ment Dis 2002, 190(9):631-637.

22. Lecrubier $Y$, Sheehan $D$, Weiller $E$, Amorim $P$, Bonora I, Sheehan $K$, Janavs J Dunbar G: The M.I.N.I. International Neuropsychiatric Interview (M.I.N.I.) A Short Diagnostic Structured Interview: Reliability and Validity According to the CIDI. Eur Psychiatr 1997, 12:224-231.

23. WHO Multi-country study on women's Health and Life Experiences. [http://www.svri.org/Questionnaire.pdf]

24. Abramsky T, Watts CH, Garcia-Moreno C, Devries K, Kiss L, Ellsberg M, Jansen $H A$, Heise $L$ : What factors are associated with recent intimate partner violence? findings from the WHO multi-country study on women's health and domestic violence. BMC Publ Health 2011, 11:109.

25. Neugebauer R, Fisher PW, Turner JB, Yamabe S, Sarsfield JA, Stehling-Ariza T: Post-traumatic stress reactions among Rwandan children and adolescents in the early aftermath of genocide. Int J Epidemiol 2009, 38(4):1033-1045.

26. de Fouchier C, Blanchet A, Hopkins W, Bui E, Ait-Aoudia M, Jehel L: Validation of a French adaptation of the Harvard Trauma Questionnaire among torture survivors from sub-Saharan African countries. Eur J Psychotraumatol 2012, 3 doi:10.3402/ejpt.v3i0.19225. Epub 2012 Dec 6.

27. Rugema L, Mogren I, Ntaganira J, Gunilla K: Traumatic episodes experienced during the genocide period in Rwanda influence life circumstances in young men and women 17 years later. BMC Public Health 2013, 13:1235

28. Oteng-Ntim E, Kopeika J, Seed P, Wandiembe S, Doyle P: Impact of Obesity on Pregnancy Outcome in Different Ethnic Groups: Calculating Population Attributable Fractions. PloS One 2013, 8(1):e53749. doi:10.1371/ journal.pone.0053749. Epub 2013 Jan 14

29. Rockhill B, Newman B, Weinberg C: Use and misuse of population attributable fractions. Am J Public Health 1998, 88(1):15-19.

30. Ellsberg M, Heise L, Pena R, Agurto S, Winkvist A: Researching domestic violence against women: methodological and ethical considerations. Stud Fam Plann 2001, 32(1):1-16.

31. Bonomi AE, Anderson ML, Rivara FP, Thompson RS: Health outcomes in women with physical and sexual intimate partner violence exposure. J Womens Health (2002) 2007, 16(7):987-997.

32. Vinck P, Pham PN: Association of exposure to intimate-partner physical violence and potentially traumatic war-related events with mental health in Liberia. Soc Sci Med (1982) 2013, 77:41-49.

33. Pham PN, Weinstein HM, Longman T: Trauma and PTSD symptoms in Rwanda: implications for attitudes toward justice and reconciliation. JAMA 2004, 292(5):602-612

34. Vinck P, Pham PN, Stover E, Weinstein HM: Exposure to war crimes and implications for peace building in northern Uganda. JAMA 2007, 298(5):543-554.

35. Sipsma H, Ofori-Atta A, Canavan M, Osei-Akoto I, Udry C, Bradley EH: Poor mental health in Ghana: who is at risk? BMC Public Health 2013, 13:288.

36. Peltzer K, Pengpid S, McFarlane J, Banyini M: Mental health consequences of intimate partner violence in Vhembe district, South Africa. General Hospital Psychiatry 2013, 35(5):545-550.

37. Vizcarra B, Hassan F, Hunter WM, Munoz SR, Ramiro L, De Paula CS: Partner violence as a risk factor for mental health among women from communities in the Philippines, Egypt, Chile, and India. Int J Inj Contr Saf Promot 2004, 11(2):125-129.

38. Campbell JC: Health consequences of intimate partner violence. Lancet 2002, 359(9314):1331-1336.

39. Resnick HS, Acierno R, Kilpatrick DG: Health impact of interpersonal violence. 2: Medical and mental health outcomes. Behav Med (Washington, DC) 1997, 23(2):65-78.

40. Ellsberg $M$, Jansen HA, Heise L, Watts CH, Garcia-Moreno C: Intimate partner violence and women's physical and mental health in the WHO multi-country study on women's health and domestic violence: an observational study. Lancet 2008, 371(9619):1165-1172.

41. Foshee VA, Benefield TS, Ennett ST, Bauman KE, Suchindran C: Longitudinal predictors of serious physical and sexual dating violence victimization during adolescence. Prev Med 2004, 39(5):1007-1016. 
42. Devries KM, Mak JY, Bacchus LJ, Child JC, Falder G, Petzold M, Astbury J, Watts $\mathrm{CH}$ : Intimate partner violence and incident depressive symptoms and suicide attempts: a systematic review of longitudinal studies. PloS Med 2013, 10(5):e1001439.

43. Jonsson U, Bohman H, Hjern A, von Knorring L, Paaren A, Olsson G, von Knorring AL: Intimate relationships and childbearing after adolescent depression: a population-based 15 year follow-up study. Soc Psychiatry Psychiatr Epidemiol 2011, 46(8):711-721.

44. Reid RJ, Bonomi AE, Rivara FP, Anderson ML, Fishman PA, Carrell DS, Thompson RS: Intimate partner violence among men prevalence, chronicity, and health effects. Am J Prev Med 2008, 34(6):478-485.

45. Pronyk PM, Hargreaves JR, Kim JC, Morison LA, Phetla G, Watts C, Busza J, Porter JD: Effect of a structural intervention for the prevention of intimate-partner violence and HIV in rural South Africa: a cluster randomised trial. Lancet 2006, 368(9551):1973-1983.

doi:10.1186/s12888-014-0315-7

Cite this article as: Umubyeyi et al:: Intimate partner violence and its contribution to mental disorders in men and women in the post genocide Rwanda: findings from a population based study. BMC Psychiatry 2014 14:315.

\section{Submit your next manuscript to BioMed Central and take full advantage of:}

- Convenient online submission

- Thorough peer review

- No space constraints or color figure charges

- Immediate publication on acceptance

- Inclusion in PubMed, CAS, Scopus and Google Scholar

- Research which is freely available for redistribution 